\title{
Long-distance migration of South African deep-water rock lobster Palinurus gilchristi
}

\author{
Johan C. Groeneveld ${ }^{1,2, *}$, George M. Branch ${ }^{2}$ \\ ${ }^{1}$ Marine and Coastal Management, Private Bag X2, Rogge Bay 8012, Cape Town, South Africa \\ ${ }^{2}$ Marine Biology Research Institute, Department of Zoology, University of Cape Town, Rondebosch 7701, South Africa
}

\begin{abstract}
Long-term movement patterns of deep-water rock lobster Palinurus gilchristi were investigated off the south coast of South Africa using tag recapture data. Over a 12 yr period (1988 to 1999), 30043 lobsters were tagged at 5 sites. From west to east, these were Cape Agulhas, West and East Agulhas Bank, Mossel Bay to Port Elizabeth, and Port Alfred. The overall recapture rate was $7.51 \%$, with individuals remaining at large for up to $10.3 \mathrm{yr}$. Overall, $547(25.8 \%)$ tagged lobsters of both sexes moved $>20 \mathrm{~km}$ within or between sites. We hypothesized that counter-current migration of juveniles would occur to redress downstream dispersal of phyllosoma larvae by the westerly flowing Agulhas Current. The vast majority of migrants $(72.6 \%)$ did prove to be immature (carapace length $<72 \mathrm{~mm}$ ) and did migrate eastwards against the prevailing flow of the Agulhas Current. The Cape Agulhas population (at the western extreme) comprised juveniles only. Over $97 \%$ migrated $>50 \mathrm{~km}$, either southeastwards offshore to the West and East Agulhas Bank sites (106 lobsters, covering a mean distance of $154 \mathrm{~km}$ ), or eastwards alongshore to the Mossel Bay to Port Elizabeth site near the center of the range (33 lobsters, $461 \mathrm{~km}$ ). The fastest $5 \%$ of migrants moved at 0.43 to $0.78 \mathrm{~km} \mathrm{~d}^{-1}$. In general, Cape Agulhas migrants reached West Agulhas Bank within $1 \mathrm{yr}$, East Agulhas Bank within 2, and Mossel Bay to Port Elizabeth within 3 yr. The West Agulhas Bank population comprised mostly juveniles and small mature individuals, and $38 \%$ migrated, all moving eastwards, either to East Agulhas Bank (66 lobsters, $46 \mathrm{~km}$ ), or to Mossel Bay to Port Elizabeth (73 lobsters, $426 \mathrm{~km}$ ). The easterly migration of $P$. gilchristi was evident but diminished at East Agulhas Bank, virtually absent at Mossel Bay to Port Elizabeth and non-existent at Port Alfred (at the eastern extreme). There was no evidence suggesting a westwards or return migration at any of the 5 sites. It is concluded that Cape Agulhas is an important settlement area for post-larvae originating between Port Elizabeth and West Agulhas Bank, and that juveniles migrate eastwards to redress the downstream displacement. The Port Alfred population is non-migratory and receives no immigrants from elsewhere, adding to other evidence that it is a separate stock, and it is inferred that phyllosoma larvae from this area use a different larval dispersal and return mechanism.
\end{abstract}

KEY WORDS: Rock lobster · Migration · Contranatant · Recruitment · Phyllosoma · Agulhas Current • Tag recapture

Resale or republication not permitted without written consent of the publisher

\section{INTRODUCTION}

Several species of rock lobsters (also called spiny lobsters) move substantial distances to achieve food, shelter or reproduction, often resulting in genetic mixing in the process (Herrnkind 1980). These movements may be nomadic (random wandering of individuals without clear start and end points), homing (periodic

*E-mail: jgroenev@mcm.wcape.gov.za excursions from a shelter with subsequent return), or they may be classified as migratory when they involve distinct parts of a population and take place over relatively long distances within a confined period (Herrnkind 1980). All 3 movement patterns may occur in a single species, often during different life history stages. For example, in the Caribbean, young individuals of Panulirus argus undergo an ontogenetic emigration from the settling area and subsequently assume either a nomadic life style over large areas of soft substrate, or characteristic homing patterns in

(C) Inter-Research $2002 \cdot$ www.int-res.com 
areas supplying adequate food and shelter (Herrnkind 1980). Most interesting, however, are spectacular mass migrations covering distances of hundreds of $\mathrm{km}$, often along distinct pathways on the seafloor and without return migrations, which have been observed in some Panulirus and Jasus species (Moore \& MacFarlane 1984, Booth 1997). Perhaps the best-known example is the $\sim 500 \mathrm{~km}$ annual unidirectional migration of $P$. ornatus, eastwards across the Gulf of Papua off southern New Guinea. This long-distance migration and that of Jasus verreauxi off NE New Zealand consist mostly of juvenile lobsters recruiting to adult spawning populations (Booth 1984, 1997, Moore \& MacFarlane 1984, Bell et al. 1987). In both cases, the planktonic phyllosoma larvae are pelagic for extended periods and disperse downstream before settling on the seafloor as pueruli or juvenile lobsters (Booth \& Phillips 1994, Cobb 1997). Subsequent post-larval migrations are generally against the prevailing current systems, defined as contranatant movements by Meek (1915), and are considered to be a behavioral mechanism to redress the downstream dispersal of larvae.

Long-distance migrations are only 1 of a number of mechanisms that can maintain the location of lobster populations in the face of strong currents. Others include the shortening of pelagic larval periods (as in clawed lobsters; Cobb 1997), strong forward-swimming capabilities of post-larvae or pueruli (Rooney \& Cobb 1991, Katz et al. 1994), larval retention in eddies (Chiswell \& Booth 1999), and oceanic larval dispersal and return processes (Pollock 1989, 1995, Booth \& Phillips 1994, Cobb 1997). Behavioral responses that retain larvae geographically close to parent populations may also come into play (Booth \& Ovenden 2000). In many cases, recruitment is ensured by a combination of these mechanisms and post-larval migration.

A firm understanding of the migration of exploited lobster species is important in terms of explaining recruitment. In some cases, it has also influenced decisions about where and when fishing should occur for rock lobsters (Street 1971, McKoy 1983, Phillips 1983, Moore \& MacFarlane 1984, Booth 1997, Noli \& Grobler 1998), or for clawed lobsters (Cooper \& Uzmann 1971, Haakonsen \& Anoruo 1994). Queuing (Herrnkind 1969) and aggregation behavior (Koyama 1971, Kelly et al. 1999) may make migrants particularly susceptible to fishing gear, which may in turn result in overfishing or localized depletion. The concentration of juveniles in particular areas may make it undesirable to target these areas because of the risk of harvesting the lobsters in a pre-reproductive state. Seasonal migrations may also affect the calculation of abundance indices, with implications for stock assessments and the management of exploited stocks.
The rock lobster Palinurus gilchristi is endemic to the South African continental shelf. It occurs on rocky substrata in moderately deep water (90 to $200 \mathrm{~m}$ ) extending from Cape Point $\left(18^{\circ} 20^{\prime} \mathrm{E}, 34^{\circ} 20^{\prime} \mathrm{S}\right)$, along the edge of the Agulhas Bank up to $200 \mathrm{~km}$ offshore, and closer inshore up to the eastern Cape Province $\left(\sim 28^{\circ} \mathrm{E}\right.$, $33^{\circ} \mathrm{S}$ ). This species supports a commercial trap-fishery along most of its range, with catches exceeding $1000 \mathrm{t}$ $\mathrm{yr}^{-1}$ during the early 1990s. Declines in catch per unit effort have, however, led to reductions in total allowable catches in recent years. Detailed descriptions of the history and management of the fishery are given by Pollock \& Augustyn (1982) and Pollock et al. (2000).

Palinurus gilchristi must be a strong candidate for long-distance migration because of its long drifting phyllosoma phase (Pollock 1995) and its occurrence in the vicinity of the strong Agulhas Current, which flows westerly along the south coast of South Africa. Consequently a mechanism is likely to exist to counter its potential westward displacement. We assessed migration of $P$. gilchristi using long-term tag recapture data spanning a $12 \mathrm{yr}$ period, coupled with population parameters of commercially caught lobsters. We predicted that migrations would be eastward (against the current), would include both sexes and would be restricted to individuals that have not yet reproduced. Current-driven larval distribution patterns are inferred from the data, and the ecological and fisheries management implications of migration in this species are discussed.

\section{MATERIALS AND METHODS}

The South African continental shelf between $18^{\circ} 20^{\prime} \mathrm{E}$ and $29^{\circ} 50^{\prime} \mathrm{E}$ and extending from the shore down to $200 \mathrm{~m}$ depth was partitioned into 478 grid blocks, each $10 \times 10 \mathrm{n}$ miles $(18 \times 18 \mathrm{~km})$, to provide a spatial context for the analysis of tag recapture and biological information. Scientists operating from commercial boats tagged lobsters at 5 sites: Cape Agulhas, West and East Agulhas Bank, Mossel Bay to Port Elizabeth, and Port Alfred (Fig. 1). These areas were geographically distinct, except for West and East Agulhas Bank, which were contiguous but could be distinguished on the basis of their different depths and the distinctly different size frequencies of lobsters occurring in each (Pollock \& Augustyn 1982, Groeneveld \& Rossouw 1995).

In total, 30043 healthy lobsters (15610 males and 14433 females), spanning the full commercial size range of 45 to $130 \mathrm{~mm}$ carapace length (CL), were tagged during 16 sampling trips between 1988 and 1998. No tagging took place in 1989, 1991 and 1994, but in the remaining years the smallest number of lobsters tagged in any one year was 2497 . For logistic 


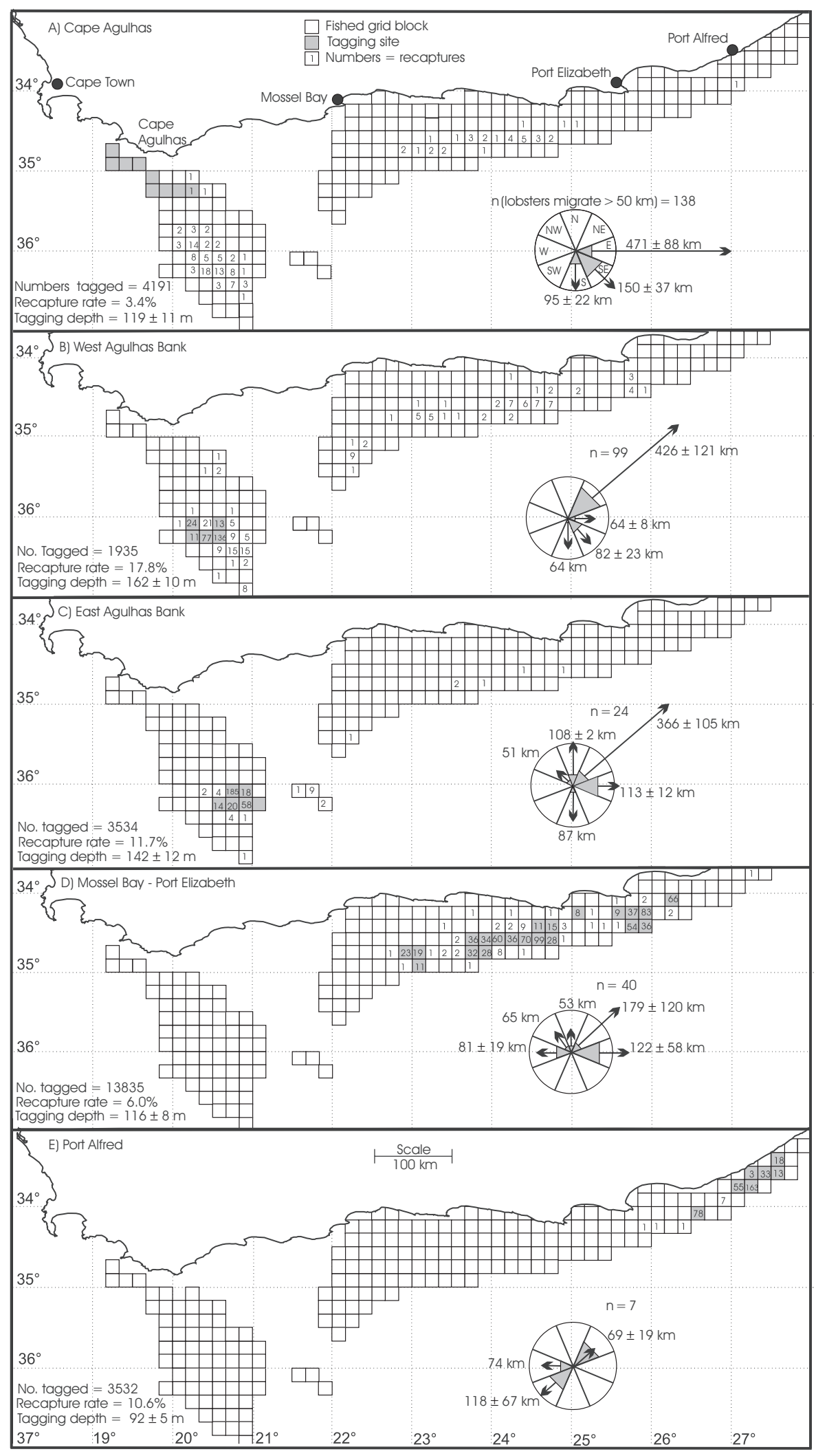

Fig. 1. Palinurus gilchristi. Release and recapture locations for 5 tagging sites off southern South Africa: (A) Cape Agulhas; (B) West Agulhas Bank; (C) East Agulhas Bank; (D) Mossel Bay to Port Elizabeth; (E) Port Alfred. The numbers of lobsters released, mean depth of release $(\mathrm{m} \pm \mathrm{SD})$ and recapture rate $(\%)$ are shown per site. Numbers in grid blocks indicate numbers of recaptures per block. The rose diagrams show the proportions of recaptured lobsters migrating $>50 \mathrm{~km}$ in each of eight $45^{\circ} \mathrm{compass}$ sectors; arrows indicate the mean distances moved $(\mathrm{km} \pm \mathrm{SD})$ per sector 
reasons it was impossible to tag lobsters at all of the sites in a given year. Effort was concentrated on the largest of the fishing grounds, Mossel Bay to Port Elizabeth, where tagging took place 8 times (May and August 1990, July 1995, April and June 1996, April and May 1997, August 1998). At West and East Agulhas Bank tagging took place on 4 occasions (May 1988, February 1992, June 1995, May 1998), at Port Alfred twice (June 1992 and May 1997), and at Cape Agulhas once (May 1993). Standard numbered plastic T-bar tags (Hallprint TBA-1) were inserted into the abdominal musculature of each lobster, dorso-laterally between the posterior edge of the carapace and first abdominal segment, or between the first and second abdominal segments. Sex, carapace length $(\mathrm{CL} \pm 0.1 \mathrm{~mm}$, measured mid-dorsally from the tip of the rostrum to the posterior edge of the carapace), geographic location, depth and date of tagging were recorded. After being tagged, lobsters were immediately released at the sea surface.

Instructions to commercial fishers were to return all recaptured lobsters to marine inspectors at landing points, irrespective of lobster size or condition. A tagreward system and a tag-draw competition were used as incentives to ensure high recovery rates. Recaptured lobsters (with details of the date, depth and location of recapture) provided information on the time between release and recapture (time at large), distance and direction moved, and the rate of movement of each lobster.

Depths at which lobsters were captured during tagging and recapture were compared within and between sites by means of an ANOVA followed by a Tukey honestly significant difference (HSD) test (Zar 1984).

Distances moved were calculated as the shortest distance between release and recapture, although this must underestimate true distances traveled because movement seldom occurs in straight lines. Error estimates were based on the characteristics of the fishery. Long lines with traps are generally 2 to $4 \mathrm{~km}$ long, and the reported capture location of a tagged lobster therefore has an error margin of $\pm 4 \mathrm{~km}$. Tag-release location (at the sea surface) also has an error margin associated with horizontal displacement of released lobsters by currents. A maximum displacement of $\pm 4 \mathrm{~km}$ was assumed and, based on the maximum combined error of $\pm 8 \mathrm{~km}$, lobsters were classified as resident (conservatively defined as those recaptured $<20 \mathrm{~km}$ from their tagging locations), short-distance migrants (20 to $50 \mathrm{~km}$ ) or long-distance migrants (>50 km).

Distances moved were compared among sites using ANOVA followed by a Tukey HSD test. Data were not transformed as the residuals met the conditions of normality and homogeneity of variance required of ANOVA. Year effects, the influence of year of tagging on the distance and direction of movement of lobsters, were compared within sites using ANOVA. Data for the year- effect analysis were restricted to lobsters at large for 180 to $550 \mathrm{~d}$ ( 0.5 to $1.5 \mathrm{yr}$ ), to limit bias as a result of immediate recaptures and longer-term movement patterns.

Student's 2-sample $t$-tests were used to compare distances moved by lobsters in 2 size classes (CL $<72$ and $\geq 72 \mathrm{~mm}$ ); $t$-tests were performed separately for males and females at each tagging site.

The null hypothesis that lobsters move in random directions after release was tested at each site, using $\chi^{2}$-tests to compare the frequencies of lobsters moving short or long distances in each of 8 directions defined by $45^{\circ}$ sectors of the compass (e.g. NE $=22.5$ to $67.5^{\circ}$ ).

Migration rates $\left(\mathrm{km} \mathrm{d}^{-1}\right)$ were estimated from lobsters that had moved $>50 \mathrm{~km}$, and mean rates were compared between sites using ANOVA. However, mean migration rates certainly underestimate actual rates because lobsters do not move in straight lines and time at large is likely longer than time spent migrating. Therefore, the migration rates of the fastest $5 \%$ of lobsters at each site were also calculated.

\section{RESULTS}

\section{Recapture percentage, size composition, sex ratios and depth range}

Tag recoveries were made throughout each calendar year (no closed seasons are enforced), and included lobsters of all sizes (no minimum size limit exists). Recoveries originated from all areas of the fishing grounds because fishing effort is high throughout the region.

Of the 30043 tagged lobsters, 2256 (7.51\%) were recaptured up to May 1999. Reliable information on tag and recapture positions was available for 2121 records, and Fig. 1 shows the grid blocks in which the recaptures were made, relative to the 5 tagging sites. Two immediate impressions are gained. First, movements occurred predominantly from west to east. Second, movement from the westerly sites was substantial, but diminished progressively from west to east and was almost non-existent at the eastern-most site.

The size composition of tagged lobsters reflected that of catches, and differed markedly between sites (Fig. 2). Sexual maturity occurs at about $71 \mathrm{~mm}$ CL over most of the region (Groeneveld \& Mellville-Smith 1994), so individuals $<72 \mathrm{~mm}$ were considered to be immature. At Cape Agulhas, catches almost exclusively comprised small immature lobsters (mean CL $=62.5 \mathrm{~mm}$ ), compared to West Agulhas Bank where the population had a mean CL of $71.3 \mathrm{~mm}$ and consisted mostly of immature lobsters and a few small mature lobsters (Fig. 2A,B). At East Agulhas Bank (mean CL $=75.8 \mathrm{~mm}$ ), the size frequency distribution was bimodal, suggesting that a cohort of small sexually immature lobsters (mode $=65 \mathrm{~mm}$ CL) coexisted 

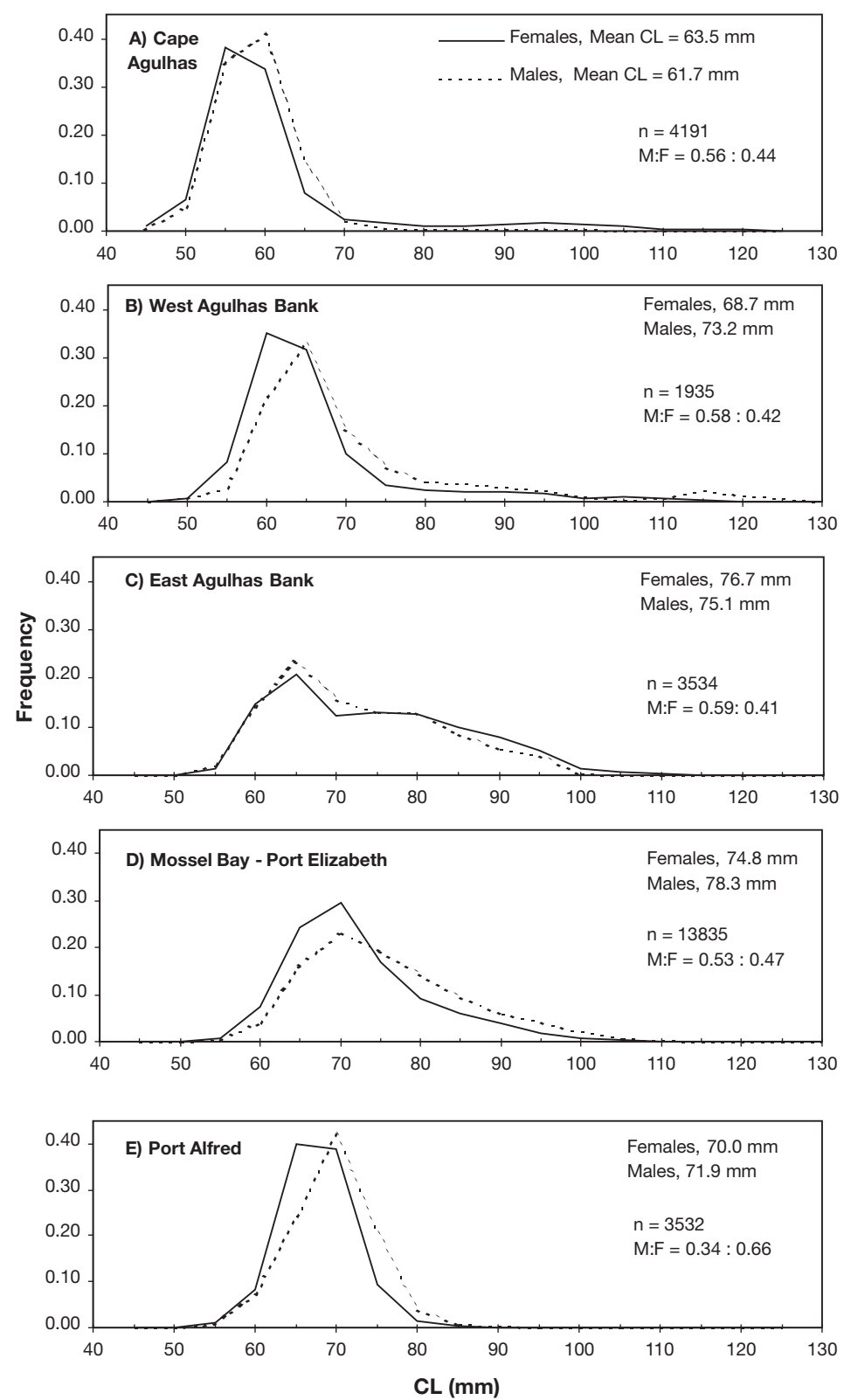

Fig. 2. Palinurus gilchristi. Carapace lengths (CL, $\mathrm{mm})$ and sex distributions of rock lobster tagged at 5 sites. Sample size (n), ratio of male to female lobsters tagged (M:F) and mean carapace length of male and female lobsters are shown for each site with one of larger sexually mature lobsters (mode $=77 \mathrm{~mm} \mathrm{CL}$ ) (Fig. 2C). The size-frequency distributions at the remaining 2 sites were both unimodal. The mean CL at Mossel Bay (76.5 mm) continued the trend of increasing size from west to east, but the mean size at Port Alfred $(70.7 \mathrm{~mm})$ was $6.8 \mathrm{~mm}$ smaller (Fig. 2D,E). Growth is slower at Port Alfred than elsewhere, and sexual maturity is reached at about $61 \mathrm{~mm}$ CL (Groeneveld \& Mellville-Smith 1994); hence, the population there comprised a mix of immature and mature lobsters, but was predominated by mature individuals.

Of the lobsters that were caught and tagged, males outnumbered females at all sites except Port Alfred, where males constituted $34 \%$ of the catch. A similar pattern emerged for lobsters that were recaptured, males being more abundant than females except at Port Alfred. The proportion of males at recapture was significantly greater than that at tagging in most cases, including Port Alfred $\left(\chi^{2}\right.$-tests; $\left.\mathrm{p}<0.05\right)$ (Table 1$)$.

Depths at which lobsters were first captured (Fig. 1) differed significantly among sites (ANOVA, $F_{4,920}=1247.7, \mathrm{p}<0.001$ ), and this was also true of the recapture depths at different sites $\left(F_{3,1335}=1537.7, \mathrm{p}<0.001\right)$. In all cases, catches made at West Agulhas Bank occurred at the deepest extreme of the fished depth range $(\sim 162 \mathrm{~m})$, whereas those made at Port Alfred occurred at the shallowest extreme ( 92 m).

\section{Distance and direction moved}

The null hypothesis that lobsters move in random directions after release was rejected for both short (20 to $50 \mathrm{~km}$ ) and long migrations (>50 km) at all 5 sites $\left(\chi^{2}\right.$-tests, $\mathrm{p}<0.05$ in all cases, excluding short migrations at Cape Agulhas, for which the sample was too small for statistical tests). At Cape Agulhas, long-distance migrants moved offshore (south and SE) or alongshore (east)

Table 1. Palinurus gilchristi. Proportion of males in tagging samples and in recaptures made at each site. Sites where $<20$ recaptures were made are not included. Asterisks (*) indicate cases where the proportion of males at recapture was significantly greater than at tagging

\begin{tabular}{|c|c|c|c|c|c|c|}
\hline \multirow{2}{*}{\multicolumn{2}{|c|}{$\begin{array}{l}\text { Sites and proportions of males } \\
\text { in tagging samples }\end{array}$}} & \multirow{3}{*}{$\begin{array}{c}\text { All recaptures } \\
0.59\end{array}$} & \multirow{3}{*}{$\begin{array}{c}\text { - Proportions of } \\
\text { West } \\
\text { Agulhas Bank }\end{array}$} & \multirow{3}{*}{$\begin{array}{l}\text { ales at recaptur } \\
\text { East } \\
\text { Agulhas Bank } \\
0.57\end{array}$} & \multirow{3}{*}{$\begin{array}{l}\text { y site } \\
\begin{array}{c}\text { Mossel Bay to } \\
\text { Port Elizabeth }\end{array} \\
0.55\end{array}$} & \multirow{3}{*}{$\begin{array}{c}\text { Port } \\
\text { Alfred } \\
\end{array}$} \\
\hline & & & & & & \\
\hline Cape Agulhas & 0.56 & & & & & \\
\hline West Agulhas Bank & 0.58 & $0.64^{*}$ & $0.66^{*}$ & 0.64 & 0.60 & \\
\hline East Agulhas Bank & 0.59 & $0.70^{*}$ & & $0.69^{*}$ & & \\
\hline Mossel Bay to Port Elizabeth & 0.53 & $0.58^{*}$ & & & $0.58^{*}$ & \\
\hline Port Alfred & 0.34 & $0.41^{*}$ & & & & $0.41^{*}$ \\
\hline
\end{tabular}


(Fig. 1A). At West and East Agulhas Bank, longdistance migrants predominantly moved northeastwards (Fig. 1B) and eastwards (Fig. 1C), respectively. At Mossel Bay to Port Elizabeth, significantly more long-distance migrants moved eastwards (east and NE) than westwards (Fig. 1D). At Port Alfred, long-distance migrants were few $(n=7)$, and their movements were mainly on the N-NE to W-SW axis (Fig. 1E).

Of the 2121 reliable recaptures, 1574 (74.2\%) moved $<20 \mathrm{~km}$, and were thus considered to be resident. Of the migrants, $239(43.7 \%)$ moved short distances of 20 to $50 \mathrm{~km}$, compared to $308(56.3 \%)$ that moved long distances of $>50 \mathrm{~km}$. The greatest recorded straightline migration was $790 \mathrm{~km}$, by a male lobster tagged at Cape Agulhas. All lobsters tagged at Cape Agulhas migrated $>20 \mathrm{~km}$, the vast majority $(97 \%)$ moving $>50 \mathrm{~km}$. Most (55\%) were recaptured 100 to $200 \mathrm{~km}$ from the tagging site, but substantial proportions (27\%) were recaptured even farther away (200 to $790 \mathrm{~km}$ ) (Fig. 3A). Of the lobsters released at West Agulhas Bank, 62\% remained resident, $10 \%$ migrated 20 to $50 \mathrm{~km}$, and $28 \%$ migrated $>50 \mathrm{~km}$ (Fig. 3B). Few lobsters tagged at the remaining 3 sites migrated $>50 \mathrm{~km}$, the proportions of resident and short-distance migrants making up $93 \%$ at East Agulhas Bank, 95\% at Mossel Bay to Port Elizabeth, and $98 \%$ at Port Alfred (Fig. 3C-E).

A comparison among sites of the distances moved by all rock lobsters showed significant differences between sites (ANOVA, $F_{4,2105}=217, \mathrm{p}<0.001$ ). A Tukey HSD test revealed that the distances moved at Cape Agulhas $(209.7 \pm 156.9 \mathrm{~km})$ differed significantly from West Agulhas Bank (105.8 $\pm 179.5 \mathrm{~km})$, but grouped the distances moved at East Agulhas Bank $(16.7 \pm 49.1 \mathrm{~km})$, Mossel Bay to Port Elizabeth (12.8 \pm $27.8 \mathrm{~km})$ and Port Alfred $(11.1 \pm 16.2 \mathrm{~km})$. A comparison of migrations $>50 \mathrm{~km}$ in the predominant E-NE direction also showed significant differences between sites (ANOVA, $F_{3,156}=59.54, \mathrm{p}<0.001 ;$ Port Alfred excluded because there were so few migrants there). A Tukey HSD test grouped migrants from Cape Agulhas (mean distance migrated $=470.9 \pm 88.1 \mathrm{~km}$ ) and West Agulhas Bank (408 $\pm 143.1 \mathrm{~km})$, but distinguished them from those at East Agulhas Bank (197.4 \pm 135.4 $\mathrm{km})$ and Mossel Bay to Port Elizabeth (127.6 \pm 65.4 $\mathrm{km})$. The distances of easterly migrations clearly declined eastwards from Cape Agulhas to Port Alfred.

\section{Time at large and distance moved}

Of 2121 recaptures, $1112(52.4 \%)$ were at large for less than $1 \mathrm{yr}, 446(21.0 \%)$ for 1 to $2 \mathrm{yr}, 251$ (11.8\%) for 2 to $3 \mathrm{yr}, 115$ (5.4\%) for 3 to $4 \mathrm{yr}$ and 101 (4.8\%) for 4 to 5 yr. A further 96 individuals $(4.5 \%)$ were at large for 5.0 to $10.3 \mathrm{yr}$.
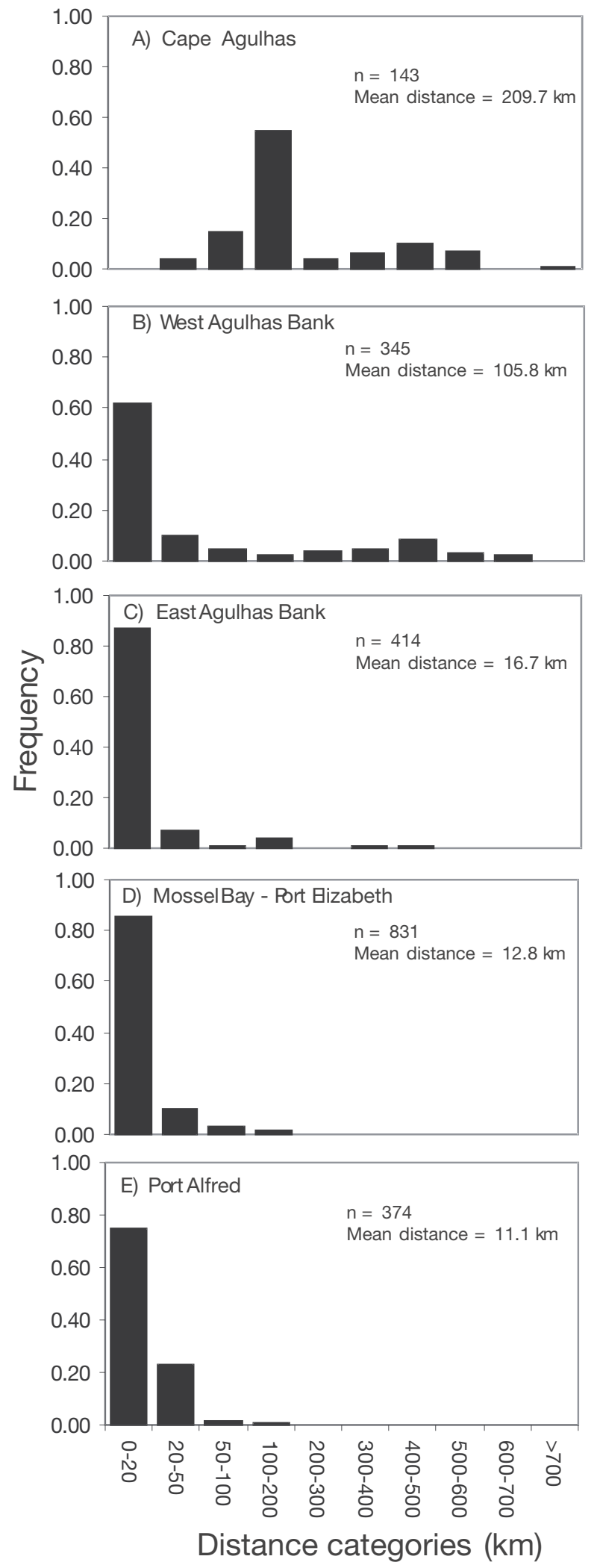

Fig. 3. Palinurus gilchristi. Frequency distributions of distances migrated $(\mathrm{km})$ by rock lobster tagged at 5 sites. Sample size $(\mathrm{n})$ and mean distance $(\mathrm{km})$ are shown for each site 
Lobsters tagged at Cape Agulhas remained free for up to $6 \mathrm{yr}$ and were recaptured in large numbers at 3 of the other 4 sites (Fig. 4A). Recaptures occurred at West Agulhas Bank within $1 \mathrm{yr}$ of tagging (and up to $6 \mathrm{yr}$ thereafter), at East Agulhas Bank 2 or more years after tagging, and at Mossel Bay to Port Elizabeth after 3 or more years. The mean distances moved by migrants from Cape Agulhas to these 3 sites ranged from 119 $\mathrm{km}$ (migrants captured at West Agulhas Bank) to 461 km (at Mossel Bay to Port Elizabeth) (Table 2). Recaptures over a prolonged period at West and East Agulhas Bank showed that some of the lobsters that migrated there from Cape Agulhas became residents and remained there, whereas others migrated onwards and were soon recaptured at Mossel Bay to Port Elizabeth. Only 3 lobsters that were tagged at Cape Agulhas were ever recaptured at their site of release, suggesting that few lobsters become resident in this area. A single lobster from Cape Agulhas found its way to Port Alfred (Fig. 4A, Table 2).

Lobsters tagged at West Agulhas Bank remained at large for up to $10.3 \mathrm{yr}$ and, over extensive periods, were recaptured at their site of release, or had moved to East Agulhas Bank and Mossel Bay to Port Elizabeth (Fig. 4B). Many lobsters that migrated to East Agulhas Bank were first recaptured within 1 yr of tagging, but those that migrated to Mossel Bay to Port Elizabeth were mostly recaptured after 2 or more years. On average, lobsters that remained at West Agulhas Bank moved $8 \mathrm{~km}$, whereas those recaptured at East Agulhas Bank and Mossel Bay to Port Elizabeth moved 45 and $426 \mathrm{~km}$, respectively (Table 2).

Most lobsters tagged at East Agulhas Bank (95\%) were recaptured in the same area within $5 \mathrm{yr}$, although
6 had migrated to Mossel Bay to Port Elizabeth and were recaptured there after being at large for 1 to $3 \mathrm{yr}$ (Fig. 4C, Table 2). Virtually all lobsters tagged at Mossel Bay to Port Elizabeth remained at that site over an $11 \mathrm{yr}$ period (Fig. 4D, Table 2). Only 1 lobster migrated, and was recaptured at Port Alfred $1.5 \mathrm{yr}$ after tagging (Table 2). The vast bulk of lobsters tagged at Port Alfred remained resident there for up to 6 yr. There were only 3 exceptions, which were recaptured near Port Elizabeth (Fig. 4E, Table 2).

The strong eastward movement from Cape Agulhas to Mossel Bay to Port Elizabeth clearly leads to a mixing of stock over this entire range. In notable contrast, only 6 individuals ever exchanged between this region and Port Alfred (Table 2).

\section{Year effects}

Year of tagging did not influence the mean distances moved in the first $1.5 \mathrm{yr}$ at large by lobsters tagged at West Agulhas Bank (ANOVA, $F_{2,111}=0.919, \mathrm{p}=0.402$ ), East Agulhas Bank $\left(F_{1,35}=4.07, \mathrm{p}=0.052\right)$ or Port Alfred $\left(F_{1,246}=1.319, \mathrm{p}=0.085\right)$ (Table 3). At Mossel Bay to Port Elizabeth distances moved did differ significantly among years $\left(F_{4,345}=3.84, \mathrm{p}=0.004\right)$, and a Tukey test grouped movements by lobsters tagged in $1988(19.79 \pm 4.47 \mathrm{~km}), 1996(24.81 \pm 37.49 \mathrm{~km})$ and $1997(20.13 \pm 43.31 \mathrm{~km})$, as opposed to those tagged in $1990(9.74 \pm 37.49 \mathrm{~km})$ and $1995(5.46 \pm 5.9 \mathrm{~km})$, which had moved shorter distances.

The direction of movements remained generally northeast- and eastwards, irrespective of the year of tagging (Table 3).

Table 2. Palinurus gilchristi. Mean time at large (yr) and distance moved (km) by rock lobster tagged at each site

\begin{tabular}{|c|c|c|c|c|c|c|}
\hline \multirow[t]{2}{*}{ Tagging site } & \multirow[t]{2}{*}{ Recapture site } & \multirow[t]{2}{*}{$\mathrm{n}$} & \multicolumn{2}{|c|}{ Time at large } & \multicolumn{2}{|c|}{ Distance moved } \\
\hline & & & Mean (yr) & $\mathrm{SD}$ & Mean $(\mathrm{km})$ & $\mathrm{SD}$ \\
\hline \multirow[t]{5}{*}{ Cape Agulhas } & Cape Agulhas & 3 & 1.47 & 0.48 & 33.02 & 1.78 \\
\hline & West Agulhas Bank & 71 & 2.31 & 1.15 & 119.46 & 31.20 \\
\hline & East Agulhas Bank & 35 & 4.34 & 1.33 & 154.02 & 46.07 \\
\hline & Mossel Bay to Port Elizabeth & 33 & 3.77 & 1.03 & 461.19 & 68.64 \\
\hline & Port Alfred & 1 & 4.03 & & 790.26 & \\
\hline \multirow[t]{3}{*}{ West Agulhas Bank } & West Agulhas Bank & 146 & 1.62 & 1.55 & 8.24 & 6.46 \\
\hline & East Agulhas Bank & 66 & 3.75 & 2.52 & 45.84 & 29.31 \\
\hline & Mossel Bay to Port Elizabeth & 73 & 3.39 & 1.62 & 426.3 & 121.82 \\
\hline \multirow[t]{3}{*}{ East Agulhas Bank } & West Agulhas Bank & 16 & 1.94 & 1.05 & 22.25 & 11.51 \\
\hline & East Agulhas Bank & 392 & 1.57 & 1.34 & 11.14 & 22.27 \\
\hline & Mossel Bay to Port Elizabeth & 6 & 2.23 & 0.83 & 365.51 & 105.67 \\
\hline Mossel Bay to & Mossel Bay to Port Elizabeth & 844 & 1.13 & 1.34 & 12.4 & 25.87 \\
\hline Port Elizabeth & Port Alfred & 1 & 1.49 & & 306.03 & \\
\hline \multirow[t]{2}{*}{ Port Alfred } & Mossel Bay to Port Elizabeth & 4 & 1.95 & 1.93 & 107.47 & 59.48 \\
\hline & Port Alfred & 369 & 0.98 & 1.22 & 10.01 & 11.66 \\
\hline
\end{tabular}



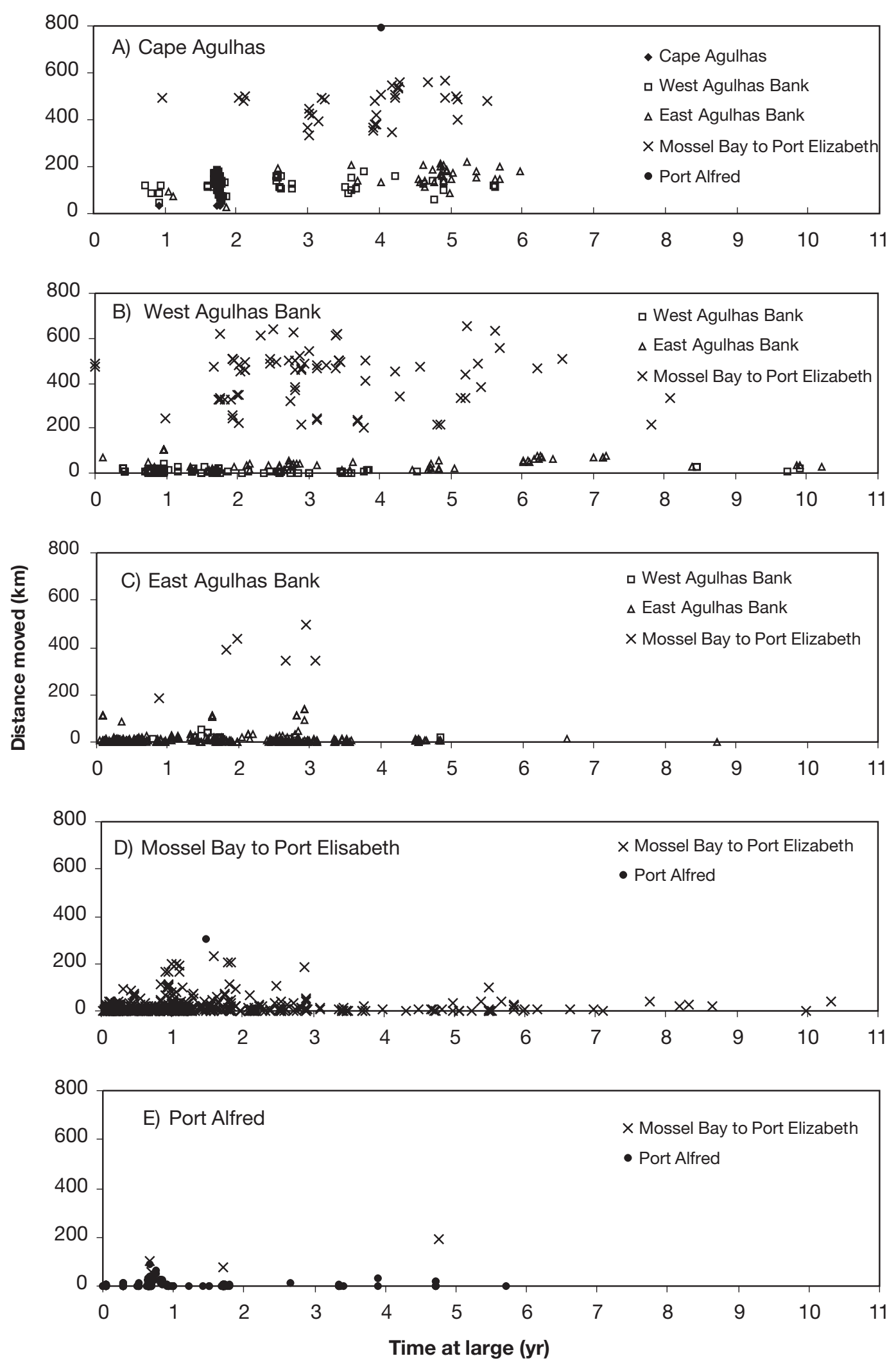

Fig. 4. Palinurus gilchristi. Distances moved $(\mathrm{km})$ plotted against time at large (yr) for rock lobster tagged at 5 sites. Symbols indicate the sites at which rock lobsters were recaptured 
Table 3. Palinurus gilchristi. Influence of year of tagging on the distance $(\mathrm{km})$ and direction moved by rock lobster. Only recaptures made within 0.5 to 1.5 yr of tagging are included. No year effect is observed at either West or East Agulhas Bank, or at Port Alfred ( $\mathrm{p}>0.05$ ). At Mossel Bay to Port Elizabeth, lobsters tagged in 1988, 1996 and 1997 moved equal distances within the first $1.5 \mathrm{yr}\left({ }^{*}\right)$, but lobsters tagged in 1990 and 1995 moved significantly shorter distances $\left({ }^{* *}\right)$

\begin{tabular}{|c|c|c|c|c|c|}
\hline Tagging site & Year tagged & $\begin{array}{l}\text { Recaptures } \\
\text { (n) }\end{array}$ & $\begin{array}{l}\text { Direction when }>50 \mathrm{~km} \\
(\mathrm{n} \text {, direction })\end{array}$ & $\begin{array}{l}\text { Distance moved } \\
\text { Mean }(\mathrm{km})\end{array}$ & $\mathrm{SD}$ \\
\hline \multirow[t]{3}{*}{ West Agulhas Bank } & 1988 & 11 & $1, \mathrm{NE}$ & 30.02 & 71.63 \\
\hline & 1992 & 88 & 8, NE & 17.22 & 28.85 \\
\hline & 1995 & 12 & & 11.75 & 5.42 \\
\hline \multirow[t]{2}{*}{ East Agulhas Bank } & 1988 & 8 & & 8.76 & 9.24 \\
\hline & 1995 & 26 & $1, \mathrm{E}$ & 17.51 & 11.15 \\
\hline \multirow[t]{5}{*}{ Mossel Bay to Port Elizabeth } & 1988 & 2 & & $19.79^{*}$ & 4.47 \\
\hline & 1990 & 206 & $3, \mathrm{E}_{;} 2, \mathrm{NE}$ & $9.74^{* *}$ & 16.65 \\
\hline & 1995 & 5 & & $5.46^{* *}$ & 5.9 \\
\hline & 1996 & 87 & $6, E_{;} 2, N E ; 3, W$ & $24.81^{*}$ & 37.49 \\
\hline & 1997 & 45 & $5, \mathrm{E}$ & $20.13^{*}$ & 43.31 \\
\hline \multirow[t]{2}{*}{ Port Alfred } & 1992 & 210 & $3, \mathrm{NE}$ & 15.56 & 12.51 \\
\hline & 1996 & 36 & $1, \mathrm{NE}_{;} 1, \mathrm{SW}$ & 6.59 & 19.25 \\
\hline
\end{tabular}

\section{Migration rate}

Mean migration rates per site, based on movements $>50 \mathrm{~km}$ but irrespective of time at large, differed significantly between sites (ANOVA, $F_{4,298}=9.9$, $\mathrm{p}<0.001)$. A Tukey HSD test showed that this was as a result of faster migration rates at West Agulhas Bank (mean $\left.0.34 \pm 0.21 \mathrm{~km} \mathrm{~d}^{-1}\right)$ than at Cape Agulhas $(0.20 \pm$ $\left.0.12 \mathrm{~km} \mathrm{~d}^{-1}\right)$, East Agulhas Bank $\left(0.29 \pm 0.20 \mathrm{~km} \mathrm{~d}^{-1}\right)$, Mossel Bay to Port Elizabeth $\left(0.26 \pm 0.19 \mathrm{~km} \mathrm{~d}^{-1}\right)$ or Port Alfred $\left(0.24 \pm 0.12 \mathrm{~km} \mathrm{~d}^{-1}\right)$. Based on the migration rates of the fastest $5 \%$ of lobsters, those tagged at West Agulhas Bank averaged $0.78 \mathrm{~km} \mathrm{~d}^{-1}$, followed by those at East Agulhas Bank $\left(0.66 \mathrm{~km} \mathrm{~d}^{-1}\right)$, Mossel Bay to Port Elizabeth $\left(0.65 \mathrm{~km} \mathrm{~d}^{-1}\right)$ and Cape Agulhas $\left(0.56 \mathrm{~km} \mathrm{~d}^{-1}\right)$. Lobsters tagged at Port Alfred moved the slowest $\left(0.43 \mathrm{~km} \mathrm{~d}^{-1}\right)$. Overall, the mean migration rate for all sites was $0.27 \pm 0.19 \mathrm{~km} \mathrm{~d}^{-1}(\mathrm{n}=298)$ and the mean for the upper 5 percentile was $0.61 \pm 0.11 \mathrm{~km} \mathrm{~d}^{-1}$.

\section{Size of lobsters that migrate}

Plots of distance moved $(\mathrm{km})$ versus CL $(\mathrm{mm})$ at tagging showed that the vast majority of migrants were $<72 \mathrm{~mm} \mathrm{CL}$, and that most lobsters $\geq 72 \mathrm{~mm} \mathrm{CL}$ remained resident (Fig. 5A-E). This trend was clear for both sexes and at all sites. At Cape Agulhas the sample almost exclusively consisted of lobsters $<72 \mathrm{~mm} \mathrm{CL}$, all of which moved. At West Agulhas Bank some lobsters $<72 \mathrm{~mm}$ CL moved whereas others remained resident, but with 1 exception all lobsters $\geq 72 \mathrm{~mm}$ CL remained resident. At both East Agulhas Bank and Mossel Bay to
Port Elizabeth most lobsters remained resident, but those that did move $>50 \mathrm{~km}$ were mostly $<72 \mathrm{~mm}$ CL.

Student's $t$-tests for each site and sex confirmed that small lobsters moved farther than large ones at West Agulhas Bank (males: $\mathrm{p}<0.001, \mathrm{n}=221$; females: $\mathrm{p}<0.001, \mathrm{n}=124)$ and at Mossel Bay to Port Elizabeth (males: $\mathrm{p}=0.019, \mathrm{n}=488$; females: $\mathrm{p}<0.001, \mathrm{n}=346$ ). At East Agulhas Bank, small males moved farther than large males ( $p=0.017, n=284)$, but small females did not move significantly farther than larger ones $(p=0.27$, $\mathrm{n}=125$ ). No difference existed between large and small individuals at Port Alfred (males: $\mathrm{p}=0.705, \mathrm{n}=154$; females: $p=0.525, n=220$ ). Virtually none of the Port Alfred lobsters, and few of the East Agulhas Bank lobsters, could however be considered as being migratory.

\section{DISCUSSION}

The tag and recapture method used to assess migration of Palinurus gilchristi relied on 5 parameters, namely the geographical positions of release and recapture, time at large, size composition and sex ratio. Actual distances moved, rates of migration, route taken and depth intervals visited were inferred from these data, and for these estimations a number of assumptions had to be made. Central to this study was the assumption that tags do not influence the behavior of $P$. gilchristi. Many individuals retained their tags over several years, with the longest recorded period between tagging and recapture being 10.3 yr. During this period, lobsters would have moulted at least 10 times (once annually, Groeneveld 1997), and it is therefore 

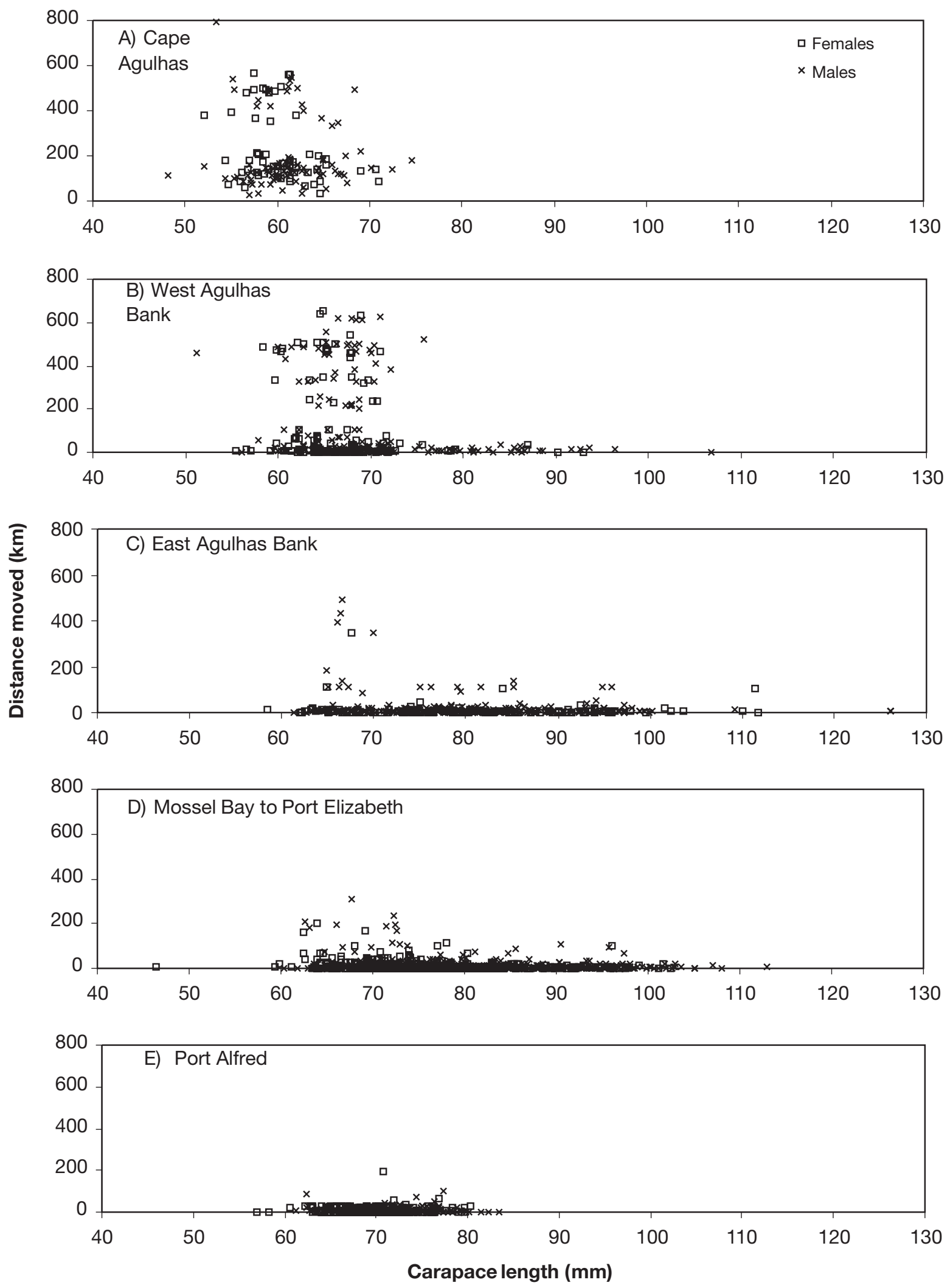

Fig. 5. Palinurus gilchristi. Distances moved $(\mathrm{km})$ plotted against carapace lengths $(\mathrm{CL}, \mathrm{mm})$ for male and female rock lobster tagged at 5 sites. $P$. gilchristi reaches sexual maturity at $\sim 72 \mathrm{~mm} \mathrm{CL}$ 
clear that tags did not easily dislodge during moulting. Furthermore, many females with tags bore eggs (J.C.G. \& G.M.B. pers. obs.). These observations imply that tags did not influence the biology of $P$. gilchristi greatly.

Tagging was not carried out contemporaneously on all 5 sites for logistical reasons, and data originating from different tagging years were combined in analyses to establish the migration pattern. A second basic assumption of this study was therefore that the distance and direction moved by lobsters were independent of the year of tagging. This assumption was tested independently at 4 of the 5 sites, and proved to be robust, with some variation of distance and direction moved in the first $1.5 \mathrm{yr}$ occurring at 1 of the sites. It is, however, considered unlikely that the results of this study were substantially influenced by year effects.

The assumptions that migration occurs along a straight line, and that the lobsters are tagged at the outset of migration and are recaptured on arrival at their destinations, are unlikely to be true, and all 3 tend to downwardly bias estimates of actual distances migrated and migration rates. It is difficult to correct for the underestimation of distances migrated, but migration rates can be more realistically estimated by relying on the rates of the fastest $5 \%$ of migrants at each site, instead of using mean migration rates. Results obtained in this manner $\left(0.61 \pm 0.11 \mathrm{~km} \mathrm{~d}^{-1}\right)$ were virtually identical to those found in studies on Jasus verreauxi $\left(0.61 \mathrm{~km} \mathrm{~d}^{-1}\right.$; Booth 1984), Panulirus ornatus $\left(0.61 \mathrm{~km} \mathrm{~d}^{-1}\right.$; Moore \& MacFarlane 1984) and P. cygnus (0.62 $\mathrm{km} \mathrm{d}^{-1}$; Phillips 1983).

Assuming that the numbers of males and females in the population are equal, the proportionally larger numbers of males caught in tagging and recapture samples imply that males have a higher catchability coefficient than females during most months of the year. Only at Port Alfred were more females than males caught (Table 1). Seasonal variations in sex ratio were investigated by Pollock \& Augustyn (1982). They concluded that males were captured more frequently than females in most months, but that this tendency did not extend to Port Alfred, where more females were observed. The disparity in sex ratios observed in migrating lobsters in the present study is thus considered to be a result of catchability fluctuations. We cannot, however, dismiss the possibility that the rate of mortality may be higher for females than males, which would account for the fact that males are proportionally more abundant in recapture samples than in tagging samples. In any event, it is clear that both male and female lobsters migrate long distances.

Directional long-distance migrations have been shown for several Panulirus and Jasus lobster species (P. argus, P. cygnus, P. ornatus, J. edwardsii and J. verreauxi; Chubb 1994). Our study showed a very specific easterly migration pattern for juvenile and small adult Palinurus gilchristi between Cape Agulhas and Mossel Bay to Port Elizabeth (Fig. 6A). The migration originates at Cape Agulhas where the population consisted almost exclusively of small juvenile lobsters with an average CL of $62.5 \mathrm{~mm}$ (Fig. 2A). From Cape Agulhas, juveniles migrated offshore in a southeasterly direction, reaching West Agulhas Bank within 1 yr, having grown to an average CL of $71.3 \mathrm{~mm}$, which is the size at which sexual maturity is attained over most of the region (Groeneveld \& Melville-Smith 1994). From West Agulhas Bank, some immature lobsters dispersed over the West and East Agulhas Bank regions and became resident there over the next year. Others migrate northeasterly and easterly to the Mossel Bay to Port Elizabeth region, which most of them reached within 2 to 3 yr of tagging at West Agulhas Bank. The populations at both East Agulhas Bank and Mossel Bay to Port Elizabeth comprised roughly equal proportions of immature and mature lobsters (Fig. 2B,C). The easterly migration of $P$. gilchristi did not extend to Port Alfred, and there was no evidence suggesting a westward or return migration from any of the 5 sites.

No recaptures were made over the inner Agulhas Bank (a rarely fished, shallower area between the coast and East Agulhas Bank). Recaptures of Cape Agulhas lobsters occurred at West and East Agulhas Bank and at Mossel Bay to Port Elizabeth, and individuals tagged at West Agulhas Bank were recaptured at Mossel Bay to Port Elizabeth. All these facts suggest that migrants originating from Cape Agulhas and West Agulhas Bank do not cross the inner Agulhas Bank en route to Mossel Bay to Port Elizabeth. Rather, they follow the shelfedge, first moving to deeper-water habitat at West Agulhas Bank (>160 m), and thereafter recruiting to shallower-water adult habitat at East Agulhas Bank $(\sim 140 \mathrm{~m})$ and Mossel Bay to Port Elizabeth $(\sim 120 \mathrm{~m})$.

The easterly migration of juvenile and small adult Palinurus gilchristi is against the southwestwards flowing Agulhas Current (Fig. 6B). This current flows swiftly (up to $300 \mathrm{~cm} \mathrm{~s}^{-1}$ ) and deeply along South Africa's east and south coasts (Boyd et al. 1992, Boyd \& Oberholster 1994). Similar migrations of juvenile or small mature spiny lobsters against the prevailing current or net coastal flow have been shown for several species. These include Jasus verreauxi off New Zealand and southern Australia, J. edwardsii off New Zealand, Panulirus cygnus off Western Australia and P. ornatus in the Gulf of Papua (McKoy 1983, Phillips 1983, Booth 1984, 1997, Moore \& MacFarlane 1984). These contranatant movements are not restricted to spiny lobsters, having also been shown for other decapods, such as scylarid lobsters (Ibacus sp.; Stewart \& Kennelly 1998) and crabs (Cancer pagurus; Edwards 1967). 


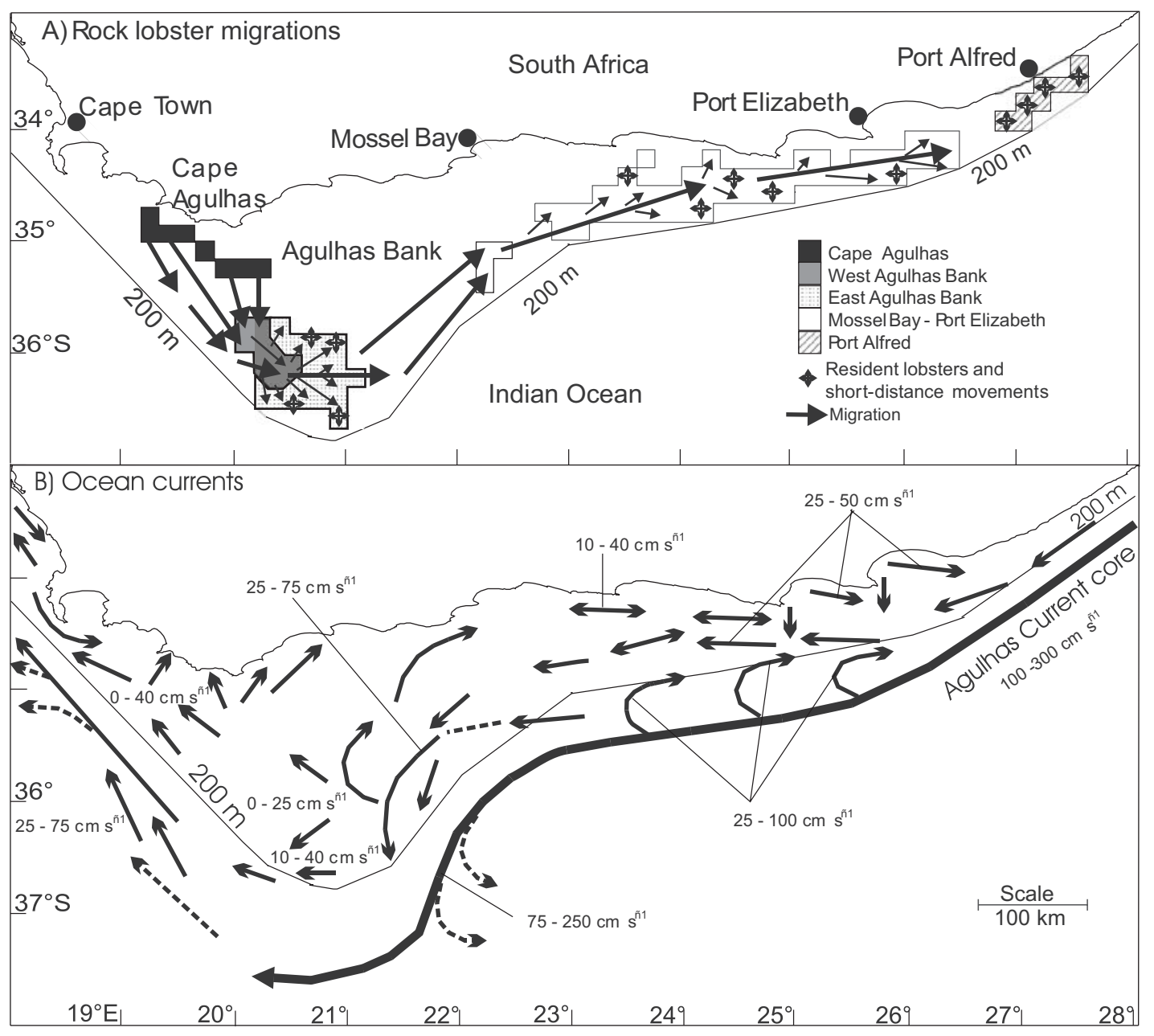

Fig. 6. Palinurus gilchristi. (A) A schematic representation of the migration of rock lobster from Cape Agulhas, southeastwards to the Agulhas Bank, and eastwards along the coast up to Port Elizabeth; (B) a diagram of the flowfield of near-surface currents off the South African south coast based on ACDP data collected between 1989 and 1992 (redrawn from Boyd et al. 1992)

Contranatant movements probably evolved to counter displacement effects of currents on the distribution of pelagic phyllosoma larvae (Herrnkind 1980). At East Agulhas Bank and Mossel Bay to Port Elizabeth the larvae of Palinurus gilchristi hatch inshore of the core Agulhas Current (the inner boundary of the Current is located between the 200 and $1000 \mathrm{~m}$ depth contours between the eastern Agulhas Bank and Port Elizabeth; Lutjeharms 1991, Boyd \& Oberholster 1994). It is probable that a large proportion of these phyllosoma larvae remain between the current and the coast, where their dispersal is regulated by coastal currents, eddies, upwelling, wind-driven surface currents, fronts and behavioral adaptations (Phillips \& McWilliam 1986, Cobb 1997, Chiswell \& Booth 1999). Despite regular reverse counter-currents and variable longshore currents that prevail inshore of the Agulhas Current (Fig. 6B), the net flow along the Cape south coast is westerly (Boyd \& Oberholster 1994), and it is therefore likely that larvae will gradually be transported in the direction of Cape Agulhas. It is suggested that Cape Agulhas acts as an important settlement area for larvae originating from East Agulhas Bank and Mossel Bay to Port Elizabeth, and that the subsequent easterly migrations of juveniles shown in this study serve to counter this displacement.

The restriction of the easterly migration to juvenile or small mature lobsters allows the population to redistribute before migrant lobsters become reproductively active, thus ensuring that larvae hatch in more favorable locations vis-à-vis the Current and the Cape Agulhas settlement area.

The presence of lobsters $<65 \mathrm{~mm} \mathrm{CL}$ at sites other than Cape Agulhas suggests that some settlement occurs throughout the distribution range of this species, although to a lesser degree than at Cape Agulhas. 
However, 2 elements hinder any assessment of the importance of the Cape Agulhas settlement area and the easterly migration relative to that of direct recruitment to the adult populations in the east. The first is the absence of information on the distribution and dispersal mechanisms of Palinurus gilchristi larvae. Second, the distribution of juveniles $<50 \mathrm{~mm} \mathrm{CL}$ is unknown. Lobsters of these small sizes are not captured by commercial traps, and a survey with smaller-mesh traps by Pollock \& Augustyn (1982) failed to locate other concentrations of juveniles. Furthermore, the cues inducing settlement of spiny lobster post-larvae are unclear (Cobb 1997, Phillips \& Pearce 1997), although some crab species have been shown to metamorphose in response to water-soluble cues associated with major components of preferred adult habitat (Weber \& Epifanio 1996), or to the presence of adult crabs or sediment from adult habitats (O'Connor 1991).

At Port Alfred, Palinurus gilchristi is essentially nonmigratory with only $1.8 \%$ of the population moving $>50 \mathrm{~km}$ (Fig. 1). Both juveniles and small adults in this region do not move directionally. It is inferred that larvae originating from this site are not transported to Cape Agulhas, but utilize different dispersal and return strategies to counter current-related displacements. The continental shelf at Port Alfred is very narrow and steep, and the Agulhas Current flows closer inshore there than at sites to the west of Port Elizabeth. Consequently, this site experiences greater exposure to the current, which reaches southwesterly velocities of 100 to $300 \mathrm{~cm} \mathrm{~s}^{-1}$ (Schumann 1987, Schumann et al. 1991, Boyd et al. 1992, Boyd \& Shillington 1994). Larvae that hatch at Port Alfred are thus more likely to be swept into the core of the Current, thereafter being transported rapidly offshore and to the southwest. A return mechanism has been postulated by Pollock (1989), although not for this site specifically. According to this postulation, larvae taken up in the Agulhas Current are transported towards the Agulhas Current retroflection, from where they are returned eastwards to Port Alfred via the eastwards flowing Agulhas return current or the south Indian Ocean gyre. An extended larval period would be required for such a long journey. Pollock (1995) and Cobb (1997) summarize the findings of various authors that spiny lobster larvae do have very long larval periods, which can be further extended by mark-time moulting.

The infrequent exchange of tagged lobsters between the Cape Agulhas to Mossel Bay to Port Elizabeth and the Port Alfred populations, and the proposed dichotomy in larval distribution mechanisms suggest that there are 2 stocks of this species and that they are geographically separated. Support for this theory is provided by the population characteristics of lobsters at Port Alfred compared to those west of there. At Port Alfred, Palinurus gilchristi has a smaller average size (Groeneveld 1993, Groeneveld \& Rossouw 1995), reaches sexual maturity at a smaller size (Groeneveld \& Melville-Smith 1994), grows slower (Groeneveld 1997) and is less fecund (Marine \& Coastal Management unpubl. data) than in populations to the west. The separate-stock theory can only be verified by a genetic study, and may have implications for the management of the fishery for this species.

An important question raised by the migration pattern illustrated for Palinurus gilchristi is whether harvesting recruits at the Cape Agulhas settlement area and at West Agulhas Bank has any effect on the adult stocks between the West Agulhas Bank and Port Elizabeth. At present, this question cannot be answered quantitatively because the proportional contribution of the Cape Agulhas recruits to the adult populations farther east has not yet been established, and it is unknown whether other major settlement areas exist. However, virtually all the Cape Agulhas lobsters migrated eastwards and became resident between West Agulhas Bank and Port Elizabeth. Furthermore, relatively few small juveniles (CL $<60 \mathrm{~mm}$ ) are captured by the commercial fisheries on fishing grounds other than Cape Agulhas and West Agulhas Bank. From these 2 facts, it is inferred that the migration is of critical importance to the adult stocks. A logical continuation of the present study is therefore to quantify the relative contribution of recruits from Cape Agulhas to the adult habitats, and to assess the effect that fishing of recruits will have on the adult populations.

Acknowledgements. This study would not have been possible without the funding and infrastructure provided by Marine and Coastal Management (Department of Environmental Affairs and Tourism, South Africa). In particular, we would like to acknowledge our former colleague, Roy MelvilleSmith (for starting the tagging program in 1988), Steven McCue, Neil van den Heever, Mark Noffke and Marico Vercuiel (for many days spent at sea on commercial fishing vessels) and Andy Cockcroft (for comments on the manuscript). Additional funding came from grants to G.M.B. from the National Research Foundation (NRF), the South African Network for Coastal and Oceanic Research (SANCOR) and the University of Cape Town. We are also grateful to the managers, skippers and crews of the south coast rock lobster fishing vessels, who assisted us with tagging and collection of data, and to the South Coast Rock Lobster Association, who contributed financially to the project.

\section{LITERATURE CITED}

Bell RS, Channells PW, MacFarlane JW, Moore R, Phillips BF (1987) Movements and breeding of the ornate rock lobster, Panulirus ornatus, in Torres Strait and on the north-east coast of Queensland. Aust J Mar Freshw Res 38:197-210 Booth JD (1984) Movements of packhorse rock lobsters (Jasus verreauxi) tagged along the eastern coast of the North 
Island, New Zealand. NZ J Mar Freshw Res 18:275-281

Booth JD (1997) Long-distance movements in Jasus spp. and their role in larval recruitment. Bull Mar Sci 61(1):111-128

Booth JD, Ovenden JR (2000) Distribution of Jasus spp. (Decapoda: Palinuridae) phyllosomas in southern waters: implications for larval recruitment. Mar Ecol Prog Ser 200:241-255

Booth JD, Phillips BF (1994) Early life history of spiny lobster. Crustaceana 66(3):271-294

Boyd AJ, Oberholster GPJ (1994) Currents off the west and south coasts of South Africa. SA Shipp News Fish Ind Rev 49(4):26-28

Boyd AJ, Shillington FA (1994) Physical forcing and circulation patterns on the Agulhas Bank. S Afr J Sci 90:114-122

Boyd AJ, Taunton-Clark J, Oberholster GPJ (1992) Spatial features of the near-surface and midwater circulation patterns off western and southern South Africa and their role in the life histories of various commercially fished species. S Afr J Mar Sci 12:189-206

Chiswell SM, Booth JD (1999) Rock lobster Jasus edwardsii larval retention by the Wairarapa eddy off New Zealand. Mar Ecol Prog Ser 183:227-240

Chubb CF (1994) Reproductive biology: issues for management. In: Phillips BF, Cobb JS, Kittaka J (eds) Spiny lobster management. Fishing News Books, Oxford, p $181-212$

Cobb JS (1997) Oceanic processes affecting lobster larvae: report from a workshop. Mar Freshw Res 48:771-775

Cooper RA, Uzmann JR (1971) Migrations and growth of deep-sea lobsters, Homarus americanus. Science 171: $288-290$

Edwards E (1967) Yorkshire crab stocks. Lab Leafl Fish Lab Burnham-on-crouch (New Series) 17:1-34

Groeneveld JC (1993) The south coast rock lobster (Palinurus gilchristi) fishery in relation to population structure, distribution and reproduction. MSc thesis, University of Port Elizabeth

Groeneveld JC (1997) Growth of spiny lobster Palinurus gilchristi (Decapoda: Palinuridae) off South Africa. S Afr J Mar Sci 18:19-30

Groeneveld JC, Melville-Smith R (1994) Size at onset of sexual maturity in the south coast rock lobster Palinurus gilchristi (Decapoda: Palinuridae). S Afr J Mar Sci 14: 219-224

Groeneveld JC, Rossouw GJ (1995) Breeding period and size in the south coast rock lobster, Palinurus gilchristi (Decapoda: Palinuridae). S Afr J Mar Sci 15:17-24

Haakonsen HO, Anoruo AO (1994) Tagging and migration of the American lobster Homarus americanus. Rev Fish Sci 2(1):79-93

Herrnkind WF (1969) Queuing behaviour of spiny lobsters. Science 164:1425-1427

Herrnkind WF (1980) Spiny lobsters: patterns of movement. In: Cobb JS, Phillips BF (eds) The biology and management of lobsters, Vol I. Physiology and behaviour. Academic Press, New York, p 349-407

Katz C, Cobb JS, Spaulding M (1994) Larval behaviour, hydrodynamic transport, and potential offshore recruitment in the American lobster Homarus americanus. Mar Ecol Prog Ser 103:265-273

Editorial responsibility: Gareth Harding (Contributing Editor), Dartmouth, Nova Scotia, Canada
Kelly S, MacDiarmid AB, Babcock RC (1999) Characteristics of spiny lobster, Jasus edwardsii, aggregations in exposed reef and sandy areas. Mar Freshw Res 50:409-416

Koyama T (1971) Spiny lobster fishing grounds off the south east coast of Africa. Bull Tokai Reg Fish Res Lab 65:17-45

Lutjeharms JRE (1991) Twintig jaar fisiese oseanologie in Suid Afrika: 'n persoonlike beskouing. S Afr J Mar Sci 10:305-320 (with English Abstract)

McKoy JL (1983) Movements of rock lobsters, Jasus edwardsii (Decapoda: Palinuridae), tagged near Stewart Island, New Zealand. NZ J Mar Freshw Res 17:357-366

Meek A (1915) Migrations in the sea. Nature 95:231

Moore R, MacFarlane JW (1984) Migrations of the ornate rock lobster, Panulirus ornatus (Fabricius), in Papua New Guinea. Aust J Mar Freshw Res 35:187-212

Noli KR, Grobler CAF (1998) Seasonal migration of Namibian rock lobster. Namibia Brief 20:126-128

O'Connor NJ (1991) Flexibility in timing of the metamorphic molt by fiddler crab megalopae Uca pugilator. Mar Ecol Prog Ser 68:234-247

Phillips BF (1983) Migrations of pre-adult western rock lobsters, Panulirus cygnus, in Western Australia. Mar Biol 76:311-318

Phillips BF, Pearce AF (1997) Spiny lobster recruitment off Western Australia. Bull Mar Sci 61(1):21-41

Phillips BF, McWilliam PS (1986) The pelagic phase of spiny lobster development. Can J Fish Aquat Sci 43: 2153-2163

Pollock DE (1989) Spiny lobsters. In: Payne AIL, Crawford RJ (eds) Oceans of life off southern Africa. Vlaeberg, Cape Town, p 70-80

Pollock DE (1995) Evolution of life-history patterns in three genera of spiny lobsters. Bull Mar Sci 57(2):516-526

Pollock DE, Augustyn CJ (1982) Biology of the rock lobster Palinurus gilchristi with notes on the South African fishery. Fish Bull S Afr 16:57-73

Pollock DE, Cockcroft AC, Groeneveld JC, Schoeman DS (2000) The fisheries for Jasus species in the south-east Atlantic and for Palinurus species of the south-west Indian Ocean. In: Phillips BF, Kittaka J (eds) Spiny lobsters: fisheries and culture, 2nd edn. Fishing News Books, Blackwell Science, Oxford, p 679

Rooney P, Cobb JS (1991) Effects of time of day, water temperature, and water velocity on swimming postlarvae of the American lobster Homarus americanus. Can J Fish Aquat Sci 48:1944-1950

Schumann EH (1987) The coastal ocean off the east coast of South Africa. Trans R Soc S Afr 46(3):215-229

Schumann EH, Lutjeharms JRE, Boyd AJ, Grundlingh ML, Brundrit GB (1991) Physical oceanography in South Africa: 1987 to 1990. S Afr J Sci 87:486-492

Stewart J, Kennelly SJ (1998) Contrasting movements of two exploited Scyllarid lobsters of the genus Ibacus off the east coast of Australia. Fish Res 36:127-132

Street RJ (1971) Rock lobster migration off Otago. NZ Comm Fish 10(6):16-17

Weber JC, Epifanio CE (1996) Response of mud crab (Panipeus herbstii) megalopae to cues from adult habitat. Mar Biol 126:655-661

Zar JH (1984) Biostatistical analysis, 2nd edn. Prentice-Hall, Englewood Cliffs, NJ

Submitted: January 30, 2001; Accepted: September 19, 2001 Proofs received from author(s): April 8, 2002 